\title{
Patogenisitas Beberapa Isolat Cendawan Entomopatogen Metarhizium spp. terhadap Telur Spodoptera litura Fabricius (Lepidoptera: Noctuidae)
}

\author{
TRIZELIA*, MY SYAHRAWATI, DAN AINA MARDIAH \\ Jurusan Hama dan Penyakit Tumbuhan, Fakultas Pertanian \\ Universitas Andalas, Kampus Limau Manis, Padang 25163
}

(diterima Desember 2010, disetujui Maret 2011)

\begin{abstract}
ABSTRAK
Patogenesitas Beberapa Isolat Cendawan Entomopatogen Metarhizium spp. terhadap Telur Spodoptera litura Fabricus (Lepidoptera: Noctuidae). Metarhizium spp. merupakan salah satu jenis cendawan entomopatogen yang dapat digunakan untuk mengendalikan hama Spodoptera litura. Tujuan dari penelitian ini adalah untuk mempelajari patogenisitas isolat Metarhizium spp. terhadap telur Spodoptera litura. Isolat Metarhizium spp. dikoleksi dari rizosfer tanaman kubis, bawang merah, bawang daun dan cabai. Hasil penelitian menunjukkan bahwa semua isolat yang diuji bersifat patogen terhadap telur $S$. litura. Mortalitas telur $S$. litura berkisar antara $19,79 \%-75,70 \%$, tergantung pada isolat. Larva instar I mati setelah 3 hari keluar dari telur dengan mortalitas tertinggi sekitar 58,65\%. Isolat Mt$\mathrm{Kb}$ merupakan isolat yang paling virulen dengan mortalitas telur dan larva instar I tertinggi dibandingkan dengan isolat lain.
\end{abstract}

KATA KUNCI : Metarhizium spp., cendawan entomopatogen, Spodoptera litura, telur, mortalitas.

\section{ABSTRACT}

Patogenicity of Some Isolates Entomopatogen Fungus, Metarhizium spp. On eggs of Spodoptera litura Fabricus (Lepidoptera: Noctuidae). Metarhizium spp. is one of the entomopathogenic fungus that can be used to control Spodoptera litura. The purpose of this research was to study the pathogenicity of Metarhizium spp. to Spodoptera litura eggs. The isolates were collected from rhizosphere of different crops i.e., cabbage, onion, leek and chili. The results showed that there was effect of all isolates on egg mortality. Mortality of $S$. litura eggs depend on the fungal isolates, ranged between 19.79\%-75.70\%. First instar larvae was also died 3 days after eclosion. The maximum mortality of first instar larvae was $58.65 \%$. At a concentration of $10^{8} \mathrm{conidia} / \mathrm{ml}$, isolate $\mathrm{Mt}-\mathrm{kb}$ had the highest virulence which caused higher mortality of eggs and first instar larvae.

KEY WORDS: Metarhizium spp., entomopathogenic fungus, Spodoptera litura, eggs, mortality.

\footnotetext{
*Korespondensi:

Telp.: +62-81374289802,

E-mail: trizelia@yahoo.com
} 


\section{PENDAHULUAN}

Ulat grayak (Spodoptera litura) merupakan salah satu jenis hama penting yang menyerang tanaman palawija dan sayuran di Indonesia. Hama ini sering mengakibatkan penurunan produktivitas bahkan kegagalan panen karena hama tersebut menyebabkan daun menjadi robek dan buah berlubang. Bila tidak segera dikendalikan maka daun atau buah tanaman di areal pertanian akan habis (Lembaga Pertanian Sehat 2008). S. litura bersifat polifag. Tanaman inangnya adalah cabai, kubis, padi, jagung, tomat, tebu, buncis, jeruk, tembakau, bawang merah, terung, kentang, kacang-kacangan (kedelai, kacang tanah), kangkung, bayam, pisang, dan tanaman hias (Marwoto \& Suharsono 2008).

Hama ini tersebar luas di daerah dengan iklim panas dan lembab dari subtropis sampai daerah tropis. Berdasarkan data Badan Pusat Statistik (2007), luas serangan ulat grayak di Sumatera Barat tahun 2005 mencapai 1.235 ha. Serangan tersebut menurun pada tahun 2006 menjadi 1.100 ha.

Hama $S$. litura menyerang tanaman budidaya pada fase vegetatif dan generatif. Pada fase vegetatif larva memakan daun tanaman yang muda sehingga tinggal tulang daun saja dan fase generatif dengan memakan polong-polong muda. Serangan S. litura menyebabkan kerusakan sekitar $12,5 \%$ dan lebih dari $20 \%$ pada tanaman umur lebih dari 20 hari setelah tanam. Serangan berat akan menyebabkan tanaman mati (Hennie Puspita et al. 2003; Adisarwanto \& Wudianto 1999).

Sejauh ini pengendalian hama tanaman yang dilakukan oleh para petani masih mengandalkan insektisida kimia (Marwoto 1992). Petani umumnya menggunakan insektisida kimia yang intensif (dengan frekuensi dan dosis tinggi). Hal ini mengakibatkan timbulnya dampak penggunaan pestisida seperti: gejala resistensi, resurjensi hama, terbunuhnya musuh alami, meningkatnya residu pada hasil, mencemari lingkungan dan gangguan kesehatan bagi pengguna (Direktorat Perlindungan Tanaman Hortikultura 2008).

Pengurangan penggunaan pestisida di areal pertanian menuntut tersedianya cara pengendalian lain yang aman dan ramah lingkungan, diantaranya dengan memanfaatkan musuh alami, seperti cendawan entomopatogen, serangga predator, dan parasitoid (Lembaga Pertanian Sehat 2008). Salah satu cendawan entomopatogen yang potensial untuk mengendalikan hama $S$. litura adalah Metarhizium spp. Metarhizium spp. dilaporkan dapat menginfeksi beberapa serangga hama seperti $S$. litura Fabricus, Spodoptera exigua Hubner, dan Coptotermes gestroi Wasmann (Kurnia 1998; Yudha 2005; Desyanti et al. 2007). Hasil penelitian Wulandari et al. (2009), menunjukkan bahwa isolat Metharhizium spp. dapat me- 
matikan larva $S$. litura berkisar antara $15-42,5 \%$.

Salah satu keuntungan penggunaan cendawan Metarhizium spp. untuk pengendalian hayati adalah dapat digunakan untuk mengendalikan berbagai tingkat perkembangan serangga mulai dari telur, larva, pupa dan imago. Metarhizium spp. dapat menginfeksi telur Riptortus linearis (Linn.) (Hemiptera:Alydidae) sehingga jumlah nimfa yang terbentuk rendah (Prayogo 2004). Samuels et al. (2002) melaporkan bahwa aplikasi $M$. anisopliae pada konsentrasi $5 \times 10^{6}$ konidia/ml terhadap telur Blissus antillus (Hemiptera: Lygalidae) menyebabkan mortalitas hingga $100 \%$. Informasi tentang kemampuan Metarhizium spp. dalam menginfeksi telur $S$. litura belum pernah dilaporkan.

Tujuan penelitian ini adalah untuk mempelajari patogenisitas Metarhizium spp. terhadap telur S. litura.

\section{BAHAN DAN METODE}

Penelitian dilaksanakan di Laboratorium Pengendalian Hayati, Jurusan Hama Penyakit Tanaman, Fakultas Pertanian, Universitas Andalas, sejak Juli 2010 hingga Oktober 2010.

\section{Koleksi dan Perbanyakan Isolat}

Isolat cendawan Metarhizium spp. yang digunakan dalam penelitian ini diisolasi dari tanah disekitar perakaran tanaman cabai, kubis, bawang merah, dan bawang daun di nagari Alahan Panjang, Kecamatan Lembah Gumanti,
Kabupaten Solok (Tabel 1). Lahan yang dipilih adalah lahan yang ditanami secara monokultur.

Koleksi cendawan entomopatogen dari tanah dilakukan dengan mengambil tanah sekitar perakaran tanaman. Sampel tanah diambil secara diagonal kemudian tanah tersebut digabung menjadi satu. Pengambilan tanah dilakukan dengan cara penggalian tanah pada kedalaman 10 - $15 \mathrm{~cm}$ dengan menggunakan sekop tangan kecil. Contoh tanah dimasukkan kedalam kantong plastik dan dibawa ke laboratorium untuk diproses lebih lanjut.

Contoh tanah diayak terlebih dahulu dengan menggunakan ayakan yang berukuran $0,4 \mathrm{~mm}$. Isolasi cendawan entomopatogen dari tanah dilakukan dengan menggunakan metoda perangkap (bait method) dengan larva Tenebrio molitor (Hasyim \& Azwana 2003; Trizelia 2005). Isolasi dengan metoda perangkap dilakukan dengan cara memasukkan tanah sebanyak 300 $\mathrm{g}$ ke dalam kotak plastik dan diberi 10 ekor larva T. molitor instar lima. Kotak kemudian diinkubasi pada suhu kamar $\left(25^{\circ} \mathrm{C}\right)$ selama 10 hari. Larva yang mati diambil dan disterilisasi permukaan dengan Natrium hipoklorit $1 \%$ dan dibilas tiga kali dengan akuades steril. Selanjutnya dimasukkan ke dalam cawan petri yang telah dialas dengan kertas saring lembab dan diinkubasi selama 5 hari. Isolasi dari larva yang terinfeksi cendawan dilakukan dengan cara mengambil konidia cendawan 
Tabel 1. Sumber isolat Metarhizium spp.

\begin{tabular}{|c|c|c|c|}
\hline Isolat & Tanaman Inang & Nagari & $\begin{array}{c}\text { Ketinggian (mdpl) / Koordinat } \\
\text { (lat/long) }\end{array}$ \\
\hline $\mathrm{Mt}-\mathrm{Cb}$ & Cabai & Alahan Panjang & $\begin{array}{l}1480 \mathrm{mdpl} / \mathrm{S}: 0^{\circ} 84^{\prime} 5,8^{\prime \prime} \\
\mathrm{E}: 100^{\circ} 47^{\prime} 7,6^{\prime \prime}\end{array}$ \\
\hline $\mathrm{Mt}-\mathrm{Kb}$ & Kubis & Alahan Panjang & $\begin{array}{l}1480 \mathrm{mdpl} / \mathrm{S}: 0^{\circ} 84^{\prime} 5,8^{\prime \prime} \\
\mathrm{E}: 100^{\circ} 47^{\prime} 7,6^{\prime \prime}\end{array}$ \\
\hline $\mathrm{Mt}-\mathrm{Bm}$ & Bawang Merah & Alahan Panjang & $\begin{array}{l}1480 \mathrm{mdpl} / \mathrm{S}: 0^{\circ} 84^{\prime} 5,8^{\prime \prime} \\
\mathrm{E}: 100^{\circ} 47^{\prime} 7,6^{\prime \prime}\end{array}$ \\
\hline Mt-Bd & Bawang Daun & Alahan Panjang & $\begin{array}{l}1480 \mathrm{mdpl} / \mathrm{S}: 0^{\circ} 84^{\prime} 5,8^{\prime \prime} \\
\mathrm{E}: 100^{\circ} 47^{\prime} 7,6^{\prime \prime}\end{array}$ \\
\hline
\end{tabular}

yang tumbuh di bagian luar tubuh larva dan ditumbuhkan pada medium Sabauraud dextrose agar dengan 2\% yeast extract (SDAY). Cendawan yang tumbuh diidentifikasi secara makroskopis dan mikroskopis. Biakan murni cendawan Metarhizium spp. yang didapat selanjutnya diperbanyak pada media SDAY dan diinkubasi selama 15 hari

\section{Perbanyakan S. litura}

Larva S. litura dikumpulkan dari pertanaman kubis di lapangan. Larvalarva ini dipelihara dalam kotak plastik dan diberi makanan berupa daun kubis yang masih segar. Makanan larva diganti setelah habis atau sudah tidak segar lagi.

Pada waktu larva akan berpupa, di dasar kotak diberi serbuk gergaji. Semua imago yang keluar dari pupa dipelihara secara massal dalam kurungan serangga yang telah diberi daun kubis segar sebagai tempat peletakan telur. Sebagai makanan imago digunakan madu dengan konsentrasi $10 \%$. Kelompok telur yang diletakkan dipindahkan ke kotak lain dan digunakan untuk pengujian.

\section{Penyiapan Suspensi Konidia}

Isolat Metarhizium spp. diperbanyak pada media SDAY dalam cawan petri pada suhu $25^{\circ} \mathrm{C}$ selama 15 hari. Konidia cendawan dipanen dengan cara menambahkan $5 \mathrm{ml}$ akuades steril dan 0,05\% Agristick sebagai bahan perata ke dalam cawan petri dan konidia dilepas dari media dengan kuas halus. Suspensi disaring dan konsentrasi konidia dihitung dengan menggunakan hemositometer.

\section{Aplikasi Konidia Metarhizium spp. terhadap Telur S. litura}

Konsentrasi konidia masing-masing isolat yang digunakan untuk pengujian patogenisitas Metarhizium spp. terhadap telur $S$. litura adalah $10^{8}$ konidia/ml. Pelaksanaan perlakuan dilakukan dengan cara menyemprotkan 2 ml suspensi konidia cendawan pada kelompok telur uji. Telur kontrol disemprot dengan aquades dengan volume yang sama. Kemudian kelompok telur tersebut dimasukkan ke dalam petri. Telur diamati setiap hari sampai menetas. Larva instar I yang baru menetas diberi pakan daun kubis segar. 
Percobaan diulang tiga kali dan percobaan disusun dalam rancangan acak lengkap (RAL). Data hasil percobaan diolah dengan sidik ragam dan dilanjutkan dengan pengujian nilai tengah menggunakan uji DNMRT pada taraf nyata $5 \%$. Variabel pengamatan adalah mortalitas telur $S$. litura, gejala infeksi Metarhizium spp. pada telur dan mortalitas larva $S$. litura instar I.

\section{HASIL DAN PEMBAHASAN}

\section{Mortalitas Telur}

Hasil uji empat isolat Metarhizium spp. terhadap telur $S$. litura menunjukkan bahwa sumber isolat mempengaruhi perkembangan telur S. litura. Analisis statistik menunjukkan bahwa ada perbedaan yang nyata antara mortalitas telur $S$. litura yang diaplikasi dengan suspensi konidia Metarhizium spp. dengan kontrol $(\mathrm{P}<0,0001)$.

Hasil penelitian menunjukkan bahwa semua isolat cendawan entomopatogen Metarhizium spp. yang diaplikasikan pada telur $S$. litura dapat menginfeksi telur $S$. litura, sehingga mempengaruhi perkembangan serangga. Mortalitas telur S. litura bervariasi, tergantung dari sumber isolat. Metarhizium spp. dari rizosfir tanaman kubis dan bawang daun lebih virulen dan mematikan telur lebih tinggi dibandingkan isolat dari rizosfir tanaman cabai dan bawang merah. Adanya perbedaan patogenisitas isolat Metarhizium spp. dari rizosfir tanaman yang berbeda diduga karena adanya se- nyawa tertentu yang dikeluarkan oleh akar tanaman. Selain dari faktor tanaman yang berbeda, adanya perbedaan patogenisitas antar isolat diduga disebabkan perbedaan karakter fisiologi antar isolat, diantaranya jumlah konidia yang dihasilkan dan daya kecambah konidia masing-masing isolat. Berdasarkan hasil penelitian Wulandari (2010), bahwa isolat Metarhizium spp. yang diisolasi dari pertanaman kubis, cabai, bawang merah, dan bawang daun menghasilkan jumlah konidia dan daya kecambah konidia yang berbeda. Isolat kubis memiliki kemampuan menghasilkan konidia tertinggi yaitu sebesar $3,50 \times 10^{8}$ konidia/ml dan isolat bawang daun menghasilkan daya kecambah konidia tertinggi yaitu 92,26\%. Isolat yang akan dipilih sebagai agens pengendali hayati harus memiliki memampuan menghasilkan konidia yang tinggi, karena konidia sangat penting untuk menginfeksi dan pemencaran cendawan (Trizelia 2005).

Kemampuan cendawan Metarhizium spp. dalam menginfeksi telur sangat bervariasi berkisar 18,67-75,36\% (Tabel 1). Hasil penelitian Samuels et al. (2002) juga menunjuk kan bahwa aplikasi isolat $M$. anisoliae terhadap telur $B$. antillus menyebabkan mortalitas telur hingga 100\%. Prayogo (2004) melaporkan bahwa cendawan entomopatogen $M$. anisopliae mampu menginfeksi telur $R$. lineraris sampai 12,67\%, sehingga persentase telur 
Tabel 1. Rata-rata mortalitas telur $S$. litura setelah aplikasi empat isolat Metarhizium spp.

\begin{tabular}{lc}
\hline \hline Isolat & Mortalitas telur $(\%) \pm$ SD \\
\hline Mt-Kb & $75,70 \pm 17,47$ a \\
Mt-Bd & $59,40 \pm 5,33$ a \\
Mt-Bm & $22,02 \pm 13,79$ b \\
Mt-Cb & $19,79 \pm 2,29 \quad$ b \\
Kontrol & $1,38 \pm 2,29$ c \\
\hline Angka yang diikuti huruf yang sama pada kolom yang sama tidak berbeda nyata menurut uji
\end{tabular}
Duncan(DNMRT) pada taraf nyata 5\%.

yang menetas menjadi nimfa menjadi rendah.

dos-Santos \& Gregorio (2003) mengemukakan bahwa telur serangga terdiri dari tiga lapisan, yaitu (1) eksokorion yang mengandung karbohidrat, (2) endokorion tersusun dari protein, dan (3) lapisan kristalin paling dalam yang mengandung protein. Beberapa senyawa yang terkandung pada lapisan korion tersebut merupakan senyawa yang dibutuhkan oleh konidia meskipun harus melalui perombakan terlebih dahulu. Karbohidrat dan protein merupakan sumber nutrisi utama yang dibutuhkan untuk pertumbuhan cendawan (Barbosa et al. 2002). Setelah miselium terbentuk, cendawan dapat mengeksploitasi sumber nutrisi yang ada di dalam telur. Pada kondisi tersebut telur sudah tidak normal atau embrio yang terbentuk di dalam telur sudah mati sehingga cendawan dalam fase saprofitik. Fase selanjutnya mi- selium menembus korion telur dan bersporulasi yang berfungsi untuk transmisi patogen ke inang yang sehat (Prayogo 2009).

\section{Gejala Infeksi Metarhizium spp. pada Telur $S$. litura}

Gejala telur S. litura yang terinfeksi Metarhizium spp. dapat dilihat pada Gambar 1. Pada awal infeksi (tiga hari setelah aplikasi) telur tampak berwarna coklat kehitaman dan mulai tumbuh miselia cendawan berwarna putih. Tahap selanjutnya (lima hari setelah aplikasi) seluruh permukaan telur telah diselimuti oleh miselium cendawan yang berwarna putih dan pada hari keenam miselium cendawan berubah warna menjadi kehijau-hijauan. Wang et al. (2005) mengemukakan bahwa telur serangga yang tidak menetas karena terinfeksi cendawan entomopatogen ditandai dengan perubahan warna telur, yaitu kusam dan tidak berkilau. 

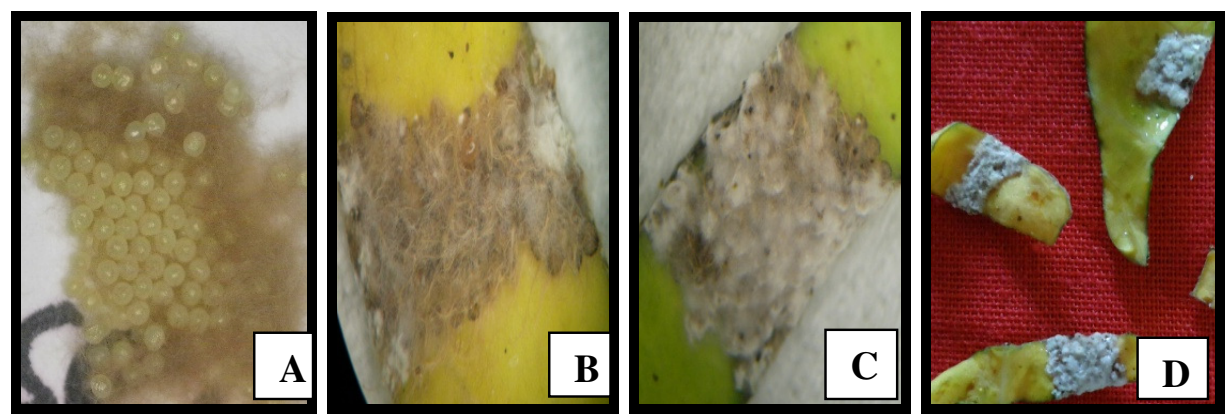

Gambar 1. Telur S. litura yang normal dan terinfeksi Metarhizium spp. $\mathrm{A}=$ telur normal, $\mathrm{B}=$ telur terinfeksi $(3 \mathrm{HSA}), \mathrm{C}=(5 \mathrm{HSA})$ dan $\mathrm{D}=$ (6 HSA)

Tabel 1. Rata-rata mortalitas larva instar I S. litura setelah aplikasi empat isolat Metarhizium spp

\begin{tabular}{lr}
\hline \hline Isolat & Mortalitas larva instar I $(\%) \pm \mathrm{SD}$ \\
\hline $\mathrm{Mt}-\mathrm{Cb}$ & $58,65 \pm 17,47 \mathrm{a}$ \\
$\mathrm{Mt}-\mathrm{Kb}$ & $48.79 \pm 5,33 \mathrm{a}$ \\
$\mathrm{Mt}-\mathrm{Bm}$ & $32,93 \pm 13,79 \mathrm{~b}$ \\
$\mathrm{Mt}-\mathrm{Bd}$ & $23,67 \pm 2,29 \mathrm{~b}$ \\
Kontrol & $3.59 \pm 2,29 \mathrm{c}$ \\
\hline Angka yang diikuti huruf yang sama pada kolom yang sama tidak berbeda nyata menurut uji \\
Duncan(DNMRT) pada taraf nyata 5\%.
\end{tabular}

\section{Mortalitas Larva Instar I}

Aplikasi Metarhizium spp. terhadap telur berpengaruh nyata terhadap kelangsungan hidup larva $S$. litura instar I $(\mathrm{P}<0,0001)$.

Mortalitas larva $S$. litura instar I maksimum 58,65\% (Metarhizium isolat cabai) dan minimum 23,67\% (Metarhizium isolat bawang daun). Semua isolat dianggap bersifat patogen terhadap larva instar I yang baru keluar dari telur. Menurut Trizelia et al. (2007), terjadinya kematian pada larva instar I disebabkan oleh larva yang baru keluar dari telur memakan kulit telur dan diduga konidia yang menempel pada kulit telur juga termakan oleh larva dan infeksi terjadi melalui saluran pencernaan. Tanada dan Kaya (1993) melaporkan, selain melalui kutikula infeksi cendawan pada serangga juga dapat terjadi melalui saluran pencernaan. Hasil penelitian Broome et al. (1976) dan Kramm dan West (1982) menunjukkan bahwa selain melalui integumen, infeksi $B$. bassiana pada serangga juga dapat melalui saluran pencernaan.

Kemungkinan lain untuk bisa terjadinya infeksi Metarhizium spp. pada larva S. litura instar I adalah melalui kontak antara konidia yang ada pada kulit telur dengan bagian ventral tubuh larva, tungkai dan alat mulut sewaktu 
larva keluar dari kulit telur. Keberhasilan proses infeksi sangat dipengaruhi oleh kemampuan konidia dari masingmasing isolat bertahan pada permukaan kulit telur. Long et al. (1998) juga melaporkan bahwa aplikasi B. bassiana pada telur Leptinotarsa decemlinata (Say) (Coleoptera: Chrysomelidae) tidak berpengaruh terhadap mortalitas telur, tetapi berpengaruh nyata terhadap mortalitas larva instar I yang baru keluar dari telur.

\section{KESIMPULAN}

Semua isolat Metarhizium spp. yang diuji bersifat patogen terhadap telur S. litura. Isolat Metarhizium spp. yang berasal dari rizosfir tanaman kubis merupakan isolat yang lebih virulen terhadap telur dan larva larva S. litura instar I dibandingkan dengan isolat yang berasal dari rizosfir tanaman cabai, bawang merah dan bawang daun.

\section{DAFTAR PUSTAKA}

Adisarwanto T dan Wudianto R. 1999. Meningkatkan Hasil Panen Kedelai di Lahan Sawah Kering, Pasang Surut. Jakarta: Penebar swadaya

Badan Pusat Statistik. 2007. Survei Pertanian. Luas dan Intensitas Serangan Ulat Grayak di Sumbar. Sumbar: Badan Pusat Statistik.

Barbosa CC, Monteiro AC, and Correia Ado-CB. 2002. Growth and sporulation of Verticillium lecanii isolates under different nutritional conditions. Pest Agropec. Braz. 37(6):821-829.

Broome JR, Sikorowski PP, Norment BR. 1976. A mechanism of pathogenicity of Beauveria bassiana on larvae of the imported fire ant. Solenopsis richteri. J. Invertebr. Pathol. 28:87-91.

Direktorat Perlindungan Tanaman Hortikultura. 2008. Pengenalan dan Pengendalian Hama Tanaman Sayuran Prioritas. Jakarta: Direktorat Perlindungan Tanaman Hortikultura.

Desyanti, Hadi YS, Yusuf S, dan Santoso T. 2007. Keefektifan beberapa spesies cendawan entomopatogen untuk mengendalikan rayap tanah Captotermes gestroi Wassman (Isoptera: Rhinotermidae) dengan Metode Kontak dan Umpan. J. Ilmu dan Teknologi Kayu Tropis 2(5):68-77.

dos-Santos DC and Gregorio EA. 2003. Deposition of the eggshell layers in the sugar cane borrer (Lepidoptera: Pyralidae): Ultrastructure aspects. Acta. Micros. 12(1):37-41.

Hennie J, Puspita F, Hendra. 2003. Kerentanan larva Spodoptera litura F terhadap virus Nuklear Polyhedrosis. Jurnal Natur Indonesia 15(2). http://www. unri. ac.id/jurnal/jurnal_nature /vol5(2). [diakses 25 Februari 2009].

Kramm KR, West DF. 1982. Termite pathogens: effects of ingested Metarhizium, Beauveria and Gliocladium conidia on worker termites (Reticulitermes sp.). $J$. Invertebr. Pathol. 40:7-11. 
Kurnia D. 1998. Efektifitas Beauveria bassiana (Balsamo) Vuillemin dan Metarhizium anisopliae (Metcnikoff) Sorokin Serta Kombinasi Keduanya terhadap Larva Spodoptera litura F (Lepidoptera:Noctuidae) [skripsi]. Padang: Universitas Andalas.

Lembaga Pertanian Sehat Develop Useful Innovation for Farmers. 2008. Virus Patogen Serangga: BioInsektisida Ramah Lingkungan. http://www.pertanian sehat. or.id/?pilih=news\&aksi=lihat\&id $=19$. [diakses 11 Oktober 2008].

Marwoto. 1992. Masalah pengendalian Hama Kedelai Di Tingkat Petani. Di dalam: Risalah Lokakarya Pengendalian Hama Terpadu Tanaman Kedelai. Balai Penelitian Tanaman Pangan, Malang, 8-10 Agustus 1991, Malang: Balai Penelitian Tanaman Pangan.

Marwoto dan Suharsono. 2008. Strategi dan komponen teknologi pengendalian ulat grayak (Spodoptera litura fabricius) pada tanaman kedelai. Jurnal Litbang Pertanian 27(4):131-136. www. pustaka-deptan.go.id/ publikasi/p 3274083.pdf. [diakses 25 Februari 2009].

Long DW, Drummond FA, Groden E. 1998. Susceptibility of Colorado potato beetle (Leptinotarsa decemlineata) eggs to Beauveria bassiana. J. Invertebr. Pathol. 71:182-183.

Prayogo Y. 2004. Keefektifan Lima Cendawan Entomopatogen untuk Mengendalikan Hama Penghisap Polong Kedelai Riptortus linearis L. (Hemiptera: Alydidae) dan Dampaknya terhadap Predator
Oxypes javanus (Araneidae: Oxypidae) [tesis]. Bogor: Institut Per-tanian Bogor.

Prayogo Y. 2009. Kajian Cendawan Entomopatogen Lecanicillium lecanii (Zimm.) (Viegas) Zare \& Gams. untuk Menekan Perkembangan Telur Hama Pengisap Polong Kedelai Riptortus linearis (F.) (Hemiptera: Alydidae) [diser tasi]. Bogor: Institut Pertanian Bogor

Tanada Y, Kaya HK. 1993. Insect Pathology. San Diego: Academic Press, INC. Harcourt Brace Jovanovich, Publisher.

Trizelia. 2005. Cendawan Entomopatogen Beauveria bassiana (Bals) Vuil. (Deuteromycotyna: Hypomycetes). Keanekaragaman Genetik, Karekteristik Fisiologi, dan Virulensinya terhadap Crocidolomia pavonana (F) [disertasi]. Bogor: Institut Pertanian Bogor.

Trizelia, Santoso T, Sosromarsono S, Rauf A, dan Sudirman L. 2007. Patogenisitas jamur entomopatogen Beauveria bassiana (Deuteromycotina; Hyphhomycetes) terhadap telur Crocidolomia pavonana (Lepidoptera: Pyralidae). Agrin. 11(1):52-59.

Wang L, Huang J, You M, Guan X, Liu B. 2005. Effects of toxin from two strains of Verticillium lecanii (Deuteromycotina: Hyphomycetes) on bioattributes of predatory ladybeteetle Delphastus catllinae (Coleoptera: Coccinellidae). J. Appl. Entomol. 129 (1):32-38.

Wulandari VW. 2010. Karakterisasi Morfologi dan Fisiologi Isolat Cendawan Metarhizium spp. 
[skripsi]. Padang: Universitas Andalas.

Yudha AJE. 2005. Efektifitas Beberapa Entomopatogen Terhadap Ha- ma Spodoptera exigua Hubner (Lepidoptera:Noctuidae) [skripsi]. Padang: Universitas Andalas. 